\title{
Wybory do Parlamentu Europejskiego w 2019 roku w Polsce - kontekst społeczny i analiza propozycji wyborczych
}

\author{
2019 Election to European Parliament in Poland - \\ Social Context and Analysis of the Election Proposals
}

\author{
Tomasz Marcinkowski*
}

\begin{abstract}
Abstrakt
W artykule ukazano kontekst społeczny wyborów do Parlamentu Europejskiego w Polsce w 2019 roku. Wysokie poparcie Polaków dla obecności państwa w strukturach Unii Europejskiej było uwzględniane w propozycjach wyborczych większości ugrupowań politycznych. Jednak partie krytyczne wobec UE, jak np. PiS czy Konfederacja odwoływały się krytycznie do tych obszarów integracji europejskiej, które są wskazywane przez część badanych jako oceniane negatywnie (wpływ integracji europejskiej na religijność czy rodzinę). Analiza zarówno zmian w zakresie opinii respondentów, jak i treści programów wyborczych wskazuje
\end{abstract}

\begin{abstract}
The article considers the Polish social context of the European Parliament elections in 2019. High approval among Poles for EU membership was taken into account by most political groups. However, parties critical of the EU (e.g. Law and Justice or Confederation) were also critical of aspects of European integration, which some respondents view negatively (e.g. its influence on religious life and the family). The analysis demonstrates that the social context was taken into account in election strategies.
\end{abstract}

Key words: European Union, European Parliament, party system, election campaign, public opinion

* Zakład Bezpieczeństwa Narodowego, Wydział Administracji i Bezpieczeństwa Narodowego, Akademia im. Jakuba z Paradyża w Gorzowie Wielkopolskim (t_marcinkowski@poczta. onet.pl); iD https://orcid.org/0000-0002-3568-5068. 
na uwzględnianie kontekstu społecznego w strategiach wyborczych.

Słowa kluczowe: Unia Europejska, Parlament Europejski, system partyjny, kampania wyborcza, opinia publiczna

\section{Wprowadzenie}

Parlament Europejski często jest uznawany za demokratyczne centrum Unii Europejskiej (Rewizorski, Przybylska-Maszner, 2012, s. 59). Podkreśla się jego znaczenie dla wzmocnienia demokratycznej legitymizacji działań całej Unii (Leach, 2004, s. 99-101). To w tym miejscu reprezentowany jest europejski głos ludu czy też głos europejskich narodów. Czynnik parlamentarny był obecny od samego początku w pracach nad tworzeniem wspólnot europejskich. Jego kompetencje i znaczenie wzrastały wraz z kolejnymi zmianami traktatowymi (Kownacki, 2005, s. 182-183). Istotnym elementem wzmocnienia PE było wprowadzenie bezpośrednich wyborów w 1979 roku (Hix, 2010, s. 123-124). Choć nie wszędzie wybory europejskie cieszą się wysoką frekwencją i często są określane jako wybory drugiej kategorii (second-order elections) (Jakubowski, 2016, s. 7), to jednak odgrywają ważną rolę w legitymizacji demokratycznej UE (Jackiewicz, 2014, s. 10-14).

W niniejszym artykule podjęto się opisu kontekstu wyborów do PE w Polsce w 2019 roku. Sygnalizowana problematyka została przedstawiona z perspektywy politologicznej. Pojęcie kontekstu odnosi się do warunków wpływających na działalność podmiotów politycznych (Jaskulski, 2019, s. 11). W kampanii dotyczącej wyborów do PE kontekst ten tworzą nie tylko krajowe uwarunkowania rywalizacji politycznej, ale także odniesienie do problematyki europejskiej. Należy więc także uwzględnić opinie dotyczące uczestnictwa Polski — z racji jej przynależności - w pracach UE oraz oceny wpływu tego uczestnictwa na wybrane obszary życia społecznego (np. rodzina czy religijność).

Jak słusznie zauważają Robert A. Dahl i Bruce Stinebrickner, polityka to wywieranie wpływu (Dahl, Stinebrickner, 2007, s. 159). Obywatele współczesnych państw europejskich należących do UE mają możliwość korzystania z tego sposobu oddziaływania na władze także na poziomie europejskim przez głosowanie. W kampanii wyborczej mamy też do czynienia z wywieraniem wpływu - na uprawnionych do głosowania - poprzez perswazję i manipulacje. Wybory do PE są elementem politycznego wymiaru integracji europejskiej. Dlatego mogą być objęte badaniami z zakresu politologii. Jest to też ten obszar, w którym nakładają się na siebie wymiary krajowy oraz europejski. Europejska 
specyfika tego procesu wyborczego powoduje, że problematyka ta mieści się w obszarze nauk politycznych, z uwzględnieniem studiów europejskich (szczególnie EU politics studies) (Ruszkowski, 2007, s. 18; Wierzchowska, 2010, s. $19-20)$.

W opracowaniu zastosowano metody ilościowe oraz jakościowe. Celem metod ilościowych jest kwantyfikacja zjawisk społecznych, a badacz dąży do ustalenia częstości (Garlicki, 2010, s. 111). „Jedną z zalet miar opisowych jest fakt, że umożliwiają obserwatorowi rozszczepienie poszczególnych obserwacji i analizę proporcji, na przykład odsetka osób, które popierają daną partię polityczną" (John, 2006, s. 221). W niniejszym artykule dokonana została analiza z wykorzystaniem statystyki opisowej na podstawie danych uzyskanych w badaniach Centrum Badania Opinii Społecznej na temat oceny przez respondentów uczestnictwa Polski w procesie integracji europejskiej (desk research).

$\mathrm{W}$ trakcie prowadzonej analizy zastosowano także metody jakościowe (Silverman, 2008, s. 145-150). Jak zauważa Fiona Devine, mają one „znaczącą, choć niedocenianą rolę w politologii" (zob. Devine 2006, s. 197). Przeprowadzona została tekstualna analizy programów wyborczych czy też, szerzej, propozycji wyborczych. Analizie poddano także wypowiedzi polityków (wywiady, wypowiedzi w trakcie spotkań z wyborcami relacjonowane na stronach internetowych) zanotowane podczas kampanii wyborczej do PE.

W artykule poddano testowaniu następujące hipotezy badawcze: 1. Partie polityczne w trakcie kampanii wyborczej do PE w 2019 roku będą uwzględniały kontekst społeczny związany z wysokim poparciem dla integracji europejskiej. 2. Partie kwestionujące poczynania UE, jak np. Prawo i Sprawiedliwość czy Konfederacja Korwin Braun Liroy Narodowcy, będą odnosiły się krytycznie do tych obszarów integracji europejskiej, które przez część badanych ocenione zostały negatywnie. W trakcie badań postawiono pytania o to, w jaki sposób, w jakim zakresie i w których programach politycznych czy — szerzej — propozycjach politycznych $\mathrm{w}$ trakcie kampanii znajdujemy odzwierciedlenie opinii Polaków wobec problematyki integracji europejskiej. Dodatkowo interesujące wydaje się pytanie o to, jakie tematy i problemy zostały wykorzystane w krytyce UE i czy w przyszłości mogą one stanowić płaszczyznę do tworzenia narracji opowiadającej się za wyjściem Polski z UE.

\section{Kontekst społeczny - opinie na temat uczestnictwa Polski w UE}

Na przebieg kampanii przed wyborami do PE miały wpływ nastroje społeczne. Polska od wielu lat charakteryzuje się wysokim poparciem dla członkostwa w Unii Europejskiej. W badaniach CBOS-u przed wyborami w marcu 2019 roku 
takie poglądy zadeklarowało 91\% respondentów. Tak znaczne (powyżej 80\%) poparcie występowało od 2008 roku (z wyjątkiem lat 2012 i 2013 — gdy spadło poniżej $80 \%$, ale i tak było stosunkowo wysokie). Ten fakt niewątpliwie musieli uwzględniać politycy planujący kampanie wyborcze w 2019 roku, zwłaszcza że poparcie dla członkostwa Polski w UE utrzymywało się na bardzo wysokim poziomie we wszystkich badanych potencjalnych elektoratach głównych ugrupowań politycznych. W analizowanych badaniach CBOS-u takie poglądy, pozytywne wobec członkostwa w UE, deklarowało: 98\% zwolenników Platformy Obywatelskiej, 92\% - popierających Kukiz'15 oraz 90\% potencjalnych wyborców PiS-u (15 lat czlonkostwa..., 2019, s. 1-2). W badaniach nie wyodrębniono elektoratu Lewicy ani Konfederacji.

Bardzo wysoki odsetek osób pozytywnie oceniających obecność Polski w UE nie występował już jednak w odniesieniu do pytań bardziej szczegółowych. W badaniach CBOS-u każdy z respondentów został poproszony o ocenę skutków członkostwa Polski w UE zarówno dla naszego państwa, jak i dla siebie osobiście. W obu przypadkach przeważały odpowiedzi pozytywne. W przypadku pytania o ocenę członkostwa Polski w UE 78\% pytanych wskazało „więcej korzyści niż strat”, 10\% — „tyle samo korzyści i strat”, 7\% — „więcej strat niż korzyści”, 5\% zaznaczyło, że „trudno powiedzieć”. Gdy to samo pytanie dotyczyło respondenta osobiście, 57\% wskazało „więcej korzyści niż strat”, 24\% „tyle samo korzyści i strat”, 5\% — „więcej strat niż korzyści”, a 14\% — „trudno powiedzieć”. Nasze członkostwo w UE jest częściej korzystnie oceniane w perspektywie ogólnej (państwa) niż indywidualnej (jego wpływ na życie, doświadczenie osobiste konkretnych ludzi). W tym drugim wypadku nie wzrasta jednak liczba odpowiedzi negatywnych (,więcej strat niż korzyści”), lecz neutralnych („tyle samo korzyści i strat” lub „trudno powiedzieć”).

Warto też przyjrzeć się, jak rozkładały się oceny członkostwa Polski w UE w elektoratach partyjnych (tab. 1-2) . W analizowanych badaniach uwzględniono elektoraty PiS-u, PO i Kukiz'15. W przypadku pytań o skutki integracji dla Polski najwięcej pozytywnych ocen wskazali wyborcy PO - 95\%, zwolennicy Kukiz' 15 - 76\%, potencjalni wyborcy PiS-u - 73\%. Także tutaj mniejsza liczba wskazań pozytywnych nie jest wynikiem wzrostu liczby deklaracji jednoznacznie negatywnych. W elektoracie PiS-u $14 \%$ badanych wskazało „tyle samo korzyści i strat”, 7\% — „więcej strat niż korzyści”, 6\% — „trudno powiedzieć”. Podobne różnice można zaobserwować w przypadku pytania o osobiste doświadczenia Polaków. W tym przypadku również w grupie sympatyków każdej z wyróżnionych partii przeważały oceny pozytywne (co najmniej 50\%). Najwięcej oceniających pozytywnie było wśród zwolenników PO - 85\%. W potencjalnym elektoracie PiS-u - 50\%, Kukiz'15 - 53\%. Najwięcej odpowiedzi ambiwalentnych (,tyle samo korzyści i strat”) było wśród wyborców: Kukiz'15 - 33\% i PiS-u - 30\% (15 lat czlonkostwa..., 2019, s. 3-5). Analiza odpowiedzi na przywołane pytanie wskazuje na to, że przygotowujący kampanię wyborczą PO 
odwołują się do jednoznacznie proeuropejskiego elektoratu. W przypadku PiS-u jest to sygnał, że część zwolenników ma jednak bardziej krytyczne podejście do integracji europejskiej i jej wpływu na Polskę czy też ich życie prywatne.

Tabela 1

Ocena wejścia Polski do Unii Europejskiej — straty i korzyści dla Polski

(elektoraty partyjne)

\begin{tabular}{|c|c|c|c|c|}
\hline $\begin{array}{l}\text { Potencjalne } \\
\text { elektoraty }\end{array}$ & $\begin{array}{c}\text { „Wejście Polski do UE } \\
\text { przynosi więcej } \\
\text { korzyści niż strat” } \\
{[\%]}\end{array}$ & $\begin{array}{c}\text { Opinia } \\
\text { niejednoznaczna } \\
{[\%]}\end{array}$ & $\begin{array}{c}\text { „Wejście Polski do UE } \\
\text { przynosi więcej strat } \\
\text { niż korzyści” } \\
{[\%]}\end{array}$ & $\begin{array}{c}\text { „Trudno powiedzieć" } \\
{[\%]}\end{array}$ \\
\hline $\mathrm{PO}$ & 95 & 2 & 1 & 2 \\
\hline Kukiz'15 & 76 & 13 & 11 & 0 \\
\hline PiS & 73 & 14 & 7 & 6 \\
\hline
\end{tabular}

Źródło: 15 lat członkostwa Polski w Unii Europejskiej. Komunikat z badań nr 59/2019 CBOS, Warszawa, kwiecień 2019, s. 5.

Tabela 2

Ocena wejścia Polski do Unii Europejskiej — straty i korzyści dla respondenta

(elektoraty partyjne)

\begin{tabular}{|c|c|c|c|c|}
\hline $\begin{array}{l}\text { Potencjalne } \\
\text { elektoraty }\end{array}$ & \begin{tabular}{|c} 
„Wejście Polski do UE \\
mnie osobiście przynosi \\
więcej korzyści \\
niż strat” \\
{$[\%]$}
\end{tabular} & $\begin{array}{c}\text { Opinia } \\
\text { niejednoznaczna } \\
{[\%]}\end{array}$ & \begin{tabular}{|c|} 
„Wejście Polski do UE \\
mnie osobiście przynosi \\
więcej strat \\
niż korzyści” \\
{$[\%]$}
\end{tabular} & $\begin{array}{c}\text { „Trudno powiedzieć" } \\
{[\%]}\end{array}$ \\
\hline $\mathrm{PO}$ & 85 & 10 & 0 & 5 \\
\hline Kukiz'15 & 53 & 33 & 2 & 12 \\
\hline PiS & 50 & 30 & 6 & 14 \\
\hline
\end{tabular}

Źródło: 15 lat członkostwa Polski w Unii Europejskiej. Komunikat z badań nr 59/2019 CBOS, Warszawa, kwiecień 2019, s. 5.

W analizowanych badaniach poproszono także o wskazanie, jakie są plusy i minusy wynikające $\mathrm{z}$ integracji Polski w ramach UE. Zdecydowanie najwięcej wskazań po stronie pozytywów dotyczyło korzyści ekonomicznych: korzyści finansowe, napływ pieniędzy z funduszy unijnych, dotacje i projekty unijne ogólnie. Porównując lata 2014 i 2019, można zaobserwować niewielki wzrost o 4 p.p. $(2014-30 \%, 2019-34 \%)$ w tej grupie odpowiedzi. Co ciekawe, drugi wynik wśród dostrzeganych plusów to: otwarcie granic, swoboda przemieszczania się, brak wiz $(2014-31 \%, 2019$ - 27\%). Mamy tu niewielki spadek liczby wskazań o 4 p.p. Największy spadek liczby wskazań wśród zalet w porównywanym okresie to: swoboda podejmowania pracy w UE, otwarty rynek pracy, swobodny przepływ pracowników $(2014-17 \%, 2019-10 \%)$. Stwierdza się tutaj spadek aż o 7 p.p. (15 lat członkostwa..., 2019, s. 5-9). Można zakładać, 
że jest to efekt m.in.: kosztów społecznych doświadczenia emigracji zarobkowej, konsekwencji sporu o migracje czy lęku przed innym, obcym (Marcinkowski, 2017, s. $119-122 ; 2019$, s. $166-167)$.

W badaniu wskazywano także na minusy członkostwa Polski w UE. Warto zauważyć, że ponad połowa badanych nie wskazała żadnych minusów. Należy jednak szczególnie zwrócić uwagę na jeden istotny wzrost między 2014 a 2019 rokiem — od 8\% w lutym 2014 roku do 23\% w marcu 2019 roku. Część pytanych za wadę członkostwa naszego państwa w UE uznała: nadmiernie ograniczoną suwerenność, ingerencję UE w sprawy Polski, rządy Brukseli czy presję unijną (15 lat czlonkostwa..., 2019, s. 5-9). Wydaje się, że może to być po części związane z narracją wskazującą na konieczność wzmocnienia roli państwa narodowego w UE. Taki sposób postrzegania polityki europejskiej jest dominujący w komunikowaniu politycznym polityków PiS-u. To także ważny element towarzyszący polityce zagranicznej rządu Zjednoczonej Prawicy (Marcinkowski, 2019, s. 123-124). Taki przyrost wskazań w tym zakresie może być także związany ze sporem pomiędzy polskim rządem a Komisją Europejską w odniesieniu do zasady praworządności (Guz-Vetter, 2019, s. 98-105). Jednocześnie wpływ na to mogły mieć różnorodne zjawiska kryzysowe, jakie wystąpiły w UE (kryzys finansowy po 2008 roku, kryzys migracyjny, brexit itp.). Wszystkie one skutkowały utratą przez część mieszkańców państw członkowskich zaufania do instytucji unijnych. Prowadziło to do oczekiwania pomocy od państwa narodowego w sytuacji kryzysowej i do zwątpienia w skuteczność działań instytucji europejskich (zob. Zielonka, 2014; Krastev, 2018). Tylko nieliczni autorzy potrafili dostrzec $\mathrm{w}$ tych przemianach jakieś pozytywy. Iwan Krastev zauważał, że paradoksalnie, w wyniku kryzysu „Europa jest zintegrowana bardziej, niż kiedykolwiek wcześniej. Kryzys ekonomiczny pozwolił wcielić w życie ideę unii bankowej. Rosnące zagrożenia terrorystyczne wymogły na Europejczykach bezprecedensową współpracę w dziedzinie bezpieczeństwa" (2018, s. 8). I dodawał, że dziś, jak nigdy, Niemca interesuje to, co się dzieje w greckiej gospodarce, a Polaków czy Węgrów — niemiecka polityka migracyjna. Zwraca to tylko uwagę na różnorodne możliwości, jakie stwarza kryzys, dając szanse często szybszych i bardziej innowacyjnych rozwiązań (albo przynajmniej takich, które wcześniej były nie do przyjęcia lub takie się wydawały).

Ciekawym zagadnieniem, jakie pojawiło się w badaniach CBOS-u, jest ocena skutków wpływu polskiej obecności w UE na trwałość polskiej rodziny. Jest to ważne ze względu na fakt, że problematyka rodziny czy religii jest ważnym tematem kampanii wyborczych w Polsce ostatnich latach. Możemy tu zauważyć zmianę we wszystkich rodzajach udzielanych odpowiedzi. Przede wszystkim między rokiem 2005 a 2019 coraz mniej osób wskazywało na to, że nie ma tu żadnego oddziaływania. Takiej odpowiedzi w 2005 roku udzieliła ponad połowa respondentów (54\%), w 2019 zaś już mniej, bo 30\%. Wzrost liczby wskazań 
nastąpił w dwóch przeciwstawnych grupach: „raczej korzystne zmiany” $-9 \%$ w 2005 roku i 30\% w 2019 roku oraz ,raczej niekorzystne zmiany” - 17\% w 2005 roku i 28\% w roku 2019 (2014 - 35\%) (15 lat czlonkostwa..., 2019, s. 13). Uzyskane wyniki wskazują na rosnącą polaryzację $\mathrm{w}$ odniesieniu do znaczenia uczestnictwa Polski w procesie integracji europejskiej ze względu na ocenę przemian społecznych (cywilizacyjnych) dotyczących rodzin. Powiązanie uczestnictwa w UE z sytuacją polskiej rodziny miało też swoje odzwierciedlenie wśród tematów, jakie podjęto w działaniach wyborczych partii prawicowych, szczególnie w programie Konfederacji.

Inne ciekawe zagadnienie, o które pytano w analizowanych badaniach, to ocena wpływu członkostwa naszego państwa w UE na religijność Polaków. W tych badaniach od początku występuje przewaga osób deklarujących, że zależność taka nie istnieje. Jednak liczba takich wskazań sukcesywnie maleje od $83 \%$ w roku 2005 do 53\% w roku 2019. Natomiast, na co warto zwrócić uwagę, wzrasta w tym okresie liczba osób odpowiadających, że ten wpływ jest negatywny. W 2005 roku uważało tak tylko $4 \%$ badanych, w ostatnich badaniach zaś jest to już 35\% (15 lat czlonkostwa..., 2019, s. 13-14). Ta zmiana kontekstu społecznego $\mathrm{w}$ zakresie postrzegania powiązania między integracją europejską a religijnością została także wykorzystana w trakcie analizowanej kampanii wyborczej. Negatywna ocena wpływu UE na kwestie religijne znalazła się w agendzie politycznej partii prawicowych (PiS, Konfederacja). Ochrona chrześcijańskiej tożsamości i wartości religijnych pojawiła się także jako element w trakcie kampanii wyborczej do PE.

W kontekście wyborów do PE warto także pokazać odpowiedzi na pytanie o przyszłość procesu integracji europejskiej. W analizowanych badaniach CBOS-u zadano pytanie o to, czy Europa powinna się bardziej zjednoczyć. Połowa pytanych odpowiedziała pozytywnie. Co piąty respondent uważał, że zjednoczenie państw członkowskich zaszło za daleko (21\%), 18\% wskazało odpowiedź ambiwalentną, a $11 \%$ — „trudno powiedzieć”. Przekonanie o konieczności dalszego jednoczenia Europy najczęściej wskazywali zwolennicy PO (70\%), rzadziej PiS-u (42\%). Jednak także wśród osób deklarujących poparcie dla partii Jarosława Kaczyńskiego zwolenników dalszej integracji było więcej niż jej przeciwników (28\%) (15 lat członkostwa..., 2019, s. 20). Trzeba jednak zauważyć, że w debacie na poziomie krajowym problematyka dotycząca dalszych kierunków procesu integracji europejskiej jest słabo obecna. Polska pomimo zapowiedzi sprzed kilku lat o przygotowaniu projektu nowego traktatu czy też rozwiązań w kwestii wzmocnienia uczestnictwa parlamentów narodowych w systemie instytucjonalnym UE nie wypracowała dotychczas żadnych propozycji, które stałyby się podstawą dalszych prac w instytucjach unijnych. Należy też zauważyć, że badani zwolennicy partii (szczególnie PO) częściej wskazują konieczność pogłębiania procesu integracyjnego, niż mówią o tym sami politycy tego ugrupowania. Taka sytuacja miała miejsce także w trakcie kampanii 
wyborczej do PE w 2019 roku, gdzie dominowały problemy krajowe lub krajowe $\mathrm{w}$ powiązaniu z europejskimi.

\section{Programy i propozycje wyborcze w wyborach do PE w Polsce w 2019 roku}

Prowadzenie kampanii wyborczej służy wzięciu udziału w debacie politycznej poprzez prezentacje własnych postulatów i propozycji oraz oddziaływanie na emocje, a przede wszystkim zdobycie poparcia w zbliżającym się głosowaniu. Kampanijna komunikacja polityczna służy jednak przede wszystkim celom pragmatycznym. Mamy tu więc promocję określonych kandydatów, budowanie pozytywnego wizerunku danego ugrupowania i negatywnego - strony przeciwnej oraz płaszczyznę argumentacji merytorycznej. Celem kampanii jest przede wszystkim zdobycie poparcia w zbliżającym się głosowaniu. Wykorzystywane jest także odwoływanie się do określonych wartości, które wskazywane jako podstawa działania określonego podmiotu politycznego mają pełnić funkcję integracyjną oraz wyróżniającą (Stępińska, Wrześniewska-Pietrzak, 2006, s. 354-355).

W trakcie kampanii wyborczej do PE większość partii czy koalicji wyborczych nie przygotowała odrębnego dokumentu programowego. Propozycje i postulaty programowe były ogłaszane na spotkaniach z wyborcami czy też na stronach internetowych oraz w materiałach wyborczych. Dlatego analizie zostaną tu poddane różnorodne materiały wyborcze związane z działaniami kampanijnymi w 2019 roku. Propozycje wyborcze dotyczyły przede wszystkim problematyki krajowej lub obszarów oddziaływania polityk europejskich na sytuację w Polsce. Rzadziej natomiast odwoływano się do problemów na poziomie całej UE czy też do różnych wizji i projektów integracji europejskiej (Cooper, Dunin-Wąsowicz, Milanese, 2019).

W kampanii wyborczej kandydatów Zjednoczonej Prawicy dominowały tematy związane $\mathrm{z}$ walką o polskie interesy i reprezentację polskiego punktu widzenia w UE. Sama Unia postrzegana była bardziej jako arena rywalizacji między państwami członkowskimi niż jako wspólnota. Jak zauważył premier Mateusz Morawiecki: „Podkreślając naszą wielką miłość do UE, walczymy na europejskim ringu o swoje, o lepszą UE, a nie tylko kulimy się w narożniku, pozwalając okładać się innym, jak to było wcześniej. Unia Europejska to owszem wspólnota interesów, ale mocno stymulowana przez interesy poszczególnych państw. I kto się zagapi, może zamiast głównej roli odgrywać mniej ciekawą rolę statysty" (Nie zgadzamy się..., 2019). W takiej sytuacji to właśnie walka na tym „europejskim ringu” była wskazywana jako misja kandydatów PiS-u i par- 
tii sojuszniczych. Politykę europejską więc przedstawiano w perspektywie neorealistycznej. Podkreślano znaczenie państw narodowych zdeterminowanych $\mathrm{w}$ walce o swoje partykularne interesy w środowisku europejskim (zob. Orłowska, 2014, s. 47-54; Dyduch, 2019, s. 32-33).

Drugim ważnym wątkiem w trakcie kampanii obozu PiS do PE były kwestie ekonomiczno-społeczne realizowane na poziomie krajowym. Rządzące ugrupowanie podkreślało znaczenie swojej polityki społecznej (program 500+ czy wypłata trzynastej emerytury). Zwracano uwagę na fakt, że jest to element dochodzenia do europejskiego poziomu życia. To właśnie ten wymiar europejskości podkreślano w przekazie kampanijnym. Jednocześnie straszono wyborców, że opozycja zechce zmienić funkcjonujące rozwiązania w zakresie polityki społecznej. Jak mówił w trakcie kampanii prezes PiS-u: „Musimy powstrzymać falę, która już zagraża Europie. Nasi oponenci zabiorą to, co my daliśmy Polakom, bo nie będą potrafili opanować finansów publicznych. Udowodnili to, gdy rządzili. Oni chcą, żeby było tak, jak wcześniej” (Obrona polskich interesów to misja polskiej delegacji, 2019).

Trzecim ważnym elementem kampanii wyborczej Zjednoczonej Prawicy były kwestie kulturowe i tożsamościowe. Odwoływanie się do wartości miało służyć budowaniu silnej tożsamości (wspólnej dla partii oraz zwolenników) i integracji wyborców. Podkreślano też wielokrotnie potrzebę wzmocnienia (lub zachowania) suwerenności państwa, ochrony wartości kultury polskiej i wartości chrześcijańskich w życiu społecznym. Podobnie jak w realizowanej przez rząd polityce zagranicznej — zwracano szczególną uwagę na podmiotowy charakter działań Polski w UE, kierowanie się interesem narodowym (czego, jak zarzucano, nie czyniła opozycja) oraz wskazywanie konieczności zmiany funkcjonowania samej UE (Marcinkowski, 2019a, s. 115-126). Działania te miały zapewnić należne Polsce miejsce w Europie.

Postulowane zmiany $\mathrm{w}$ funkcjonowaniu systemu instytucjonalnego UE opisał m.in. kandydujący do PE były minister spraw zagranicznych Witold Waszczykowski (Unia się kurczy, 2019). W jego opinii jest potrzebny powrót do korzeni tworzonych przez Roberta Schumana czy Konrada Adenauera. Ma to oznaczać: pierwszeństwo współpracy gospodarczej przed innymi obszarami współpracy, zerwanie z protekcjonizmem i odejście od „timmermanizacji” prawa europejskiego służącego narzucaniu niektórym państwom członkowskim określonych rozwiązań w ich sprawach wewnętrznych. Były minister wskazał też na potrzebę budowy „Europy ojczyzn”, w której Komisja Europejska równoważyłaby siłę największych państw. Zwracał też uwagę na potrzebę wzmocnienia roli parlamentów narodowych: „Po traktacie lizbońskim, który zmienił sposób podejmowania decyzji w Radzie Europejskiej, okazało się, że kraje większe mają znaczącą przewagę nad mniejszymi, a Komisja Europejska tej przewagi nie równoważy. Chodzi więc o to, by tę nierównowagę zlikwidować, na przykład poprzez większe uprawomocnienie parlamentów narodowych" (Unia się 
kurczy, 2019). Zwraca jednak uwagę niespójność deklarowanych propozycji, które jednocześnie zawierają ograniczanie procesu integracji (przede wszystkim współpraca gospodarcza) i jej rozwój w kierunku nowych obszarów współpracy politycznej (parlamenty narodowe).

Należy też zauważyć, że wśród kandydatów obozu Zjednoczonej Prawicy można było znaleźć pewne różnice poglądów w kwestiach europejskich. Przykładowo, Waszczykowski w analizowanym powyżej wywiadzie (Unia się kurczy, 2019) nie był przekonany o tym, czy Polska zyskuje ekonomicznie na członkostwie w UE. Wskazywał, że wymaga to dopiero dokonania bilansu. Przeciwnego zdania była minister Jadwiga Emilewicz (Porozumienie; Latwo możemy stracić dorobek..., 2019), podkreślając, że korzyści z członkostwa są jednoznaczne i obopólne. Jej zdaniem nasz kraj jest największym beneficjentem środków finansowych z UE, a pomimo wielu zjawisk kryzysowych to UE nadal pozostaje gwarantem bezpieczeństwa i dobrobytu (Latwo możemy stracić dorobek..., 2019).

Minister Emilewicz zwracała uwagę także na znaczenie tożsamości narodowych w Europie. W jej ocenie są one najlepiej reprezentowane w Radzie Europejskiej. Podkreślała, że Polska w wielu obszarach jest zwolennikiem wzmocnienia integracji (ochrona granic zewnętrznych UE, gospodarka cyfrowa, w tym szczególnie swobodny przepływ danych, dyrektywa usługowa i jej pełne wdrożenie). Co ciekawe, w swojej wypowiedzi minister w rządzie Morawieckiego nie wykluczała przyjęcia przez Polskę waluty euro. W jej przekonaniu Polska nie powinna zamykać się na taką szansę, a jej realizacja będzie możliwia, „kiedy będziemy wiedzieć, że strefa euro jest stabilna i wolna od ryzyk krajów południa, zaś wejście do strefy euro nie spowoduje gwałtownego wzrostu cen" (Łatwo możemy stracić dorobek..., 2019).

Powołanie koalicji partii opozycyjnych wobec rządu i przyjęcie nazwy „Koalicja Europejska" zapowiadało próbę stworzenia w trakcie kampanii wyborczej wrażenia rywalizacji między tym, co proeuropejskie, i tym, co przeciwne UE. Program wyborczy tego ugrupowania został zaprezentowany w dziesięciu punktach. Obejmowały one takie zagadnienia, jak m.in.: wyrównywanie poziomu życia obywateli, fundusze europejskie dla obywateli i samorządów, czyste powietrze i tania energia, ochrona zdrowia, równe szanse dla rolnictwa i polepszenie jakości żywności, spójność transportowa i komunikacyjna oraz bezpieczeństwo państwa. Wśród propozycji Koalicji Europejskiej znalazły się postulaty zarówno ekonomiczne, jak i polityczne. Celem kandydatów tej Koalicji miało być „trwałe zakorzenienie narodowego i indywidualnego losu Polek i Polaków na Zachodzie" (Materiat KWW Koalicja Europejska..., 2019). Jednoznacznie zapowiadano zerwanie z izolacją Polski w Europie. Zarzucano jednocześnie Zjednoczonej Prawicy, że osłabienie pozycji naszego państwa w UE jest wynikiem polityki obecnego rządu. Zapowiadano przywrócenie znaczenia wartości europejskich, takich jak praworządność, demokracja i solidarność. Wskazywano też na szcze- 
gólne znaczenie równości w zakresie płci oraz egzekwowanie praw mniejszości czy osób z niepełnosprawnościami.

W trakcie kampanii wyborczej zapowiadano ,zapewnienie takich samych standardów: praw i wolności, poziomu życia, możliwości rozwoju, bezpieczeństwa" (Materiat KWW Koalicja Europejska..., 2019) jak w Europie Zachodniej. W odniesieniu do gospodarki wskazywano na potrzebę wzmocnienia jednolitego rynku oraz na możliwość dostępu do rynków trzecich. Podkreślano konieczność zapewnienia równej konkurencji, także w zakresie rynku usług. W zakresie rynku pracy znalazły się tutaj bardziej lewicowe postulaty walki o lepsze warunki pracy, w tym przeciwstawienie się zatrudnianiu bez umowy czy godziwego wynagrodzenia, a także sprzeciw wobec często fikcyjnego samozatrudnienia. Zapowiadano obronę wysokości kwot uzyskiwanych przez Polskę w ramach funduszy europejskich. Jednocześnie postulowano zwiększenie udziału samorządów w ich dystrybucji. Przedstawiono także pomysł wykorzystania funduszy europejskich do inwestycji w sektor zielonej energii oraz deklarowano walkę o prawdziwą równość szans w obszarze rolnictwa europejskiego. Wśród bardziej konkretnych propozycji Koalicji Europejskiej znalazła się zapowiedź utworzenia Europejskiego Programu Onkologicznego czy wprowadzenie europejskiej legitymacji studenckiej i szkolnej zapewniającej zniżki oraz możliwość korzystania z opieki zdrowotnej w krajach członkowskich (Materiat KWW Koalicja Europejska..., 2019).

W kampanii kandydatów Koalicji Obywatelskiej pojawiał się także temat waluty euro. Była polska komisarz Danuta Hübner (Jestem realistka..., 2019) podkreślała, że po finalizacji brexitu większość gospodarek państw członkowskich UE będzie należała do strefy euro. Zwracała uwagę na potrzebę silniejszej integracji państw członkowskich wobec coraz poważniejszych wyzwań w zakresie bezpieczeństwa, globalizacji czy zmian klimatu i konsekwencji tych zmian. Jednocześnie podkreśliła, że w jej ocenie taki proces nie ma prowadzić do powstania wspólnego, jednego państwa europejskiego. Problemem jest raczej możliwość zaistnienia procesów osłabiania spójności wewnętrznej UE. Może to prowadzić do fragmentaryzacji procesu integracji europejskiej i jej realizacji w „różnych prędkościach”. Zależeć to będzie jednak ostatecznie od państw członkowskich (Jestem realistka..., 2019).

Program Wiosny przygotowany na wybory do PE należy zakwalifikować jako lewicowy czy liberalno-lewicowy. W sferze zarówno kulturowo-światopoglądowej, jak i społecznej znalazło się tu wiele postulatów charakterystycznych dla europejskiej lewicy. Wśród postulatów z zakresu polityki gospodarczej i społecznej znalazły się takie, jak m.in.: stworzenie europejskiego programu mieszkaniowego (10 mln mieszkań w Europie), bezpłatny transport publiczny dla młodych Europejczyków oraz bezpłatne podróżowanie koleją w miesiącach letnich, wsparcie dla międzynarodowej wymiany studentów oraz 
osób odbywających staże, stworzenie programu „Erasmus junior” dla uczniów szkół średnich.

Część propozycji dotyczyła praw kobiet. Wiosna proponowała m.in. wprowadzenie Europejskiej Karty Praw Kobiet. Ma ona zagwarantować wszystkim Europejkom: powszechny dostęp do antykoncepcji (w tym tzw. antykoncepcji awaryjnej), dostęp do bezpiecznego i legalnego zabiegu przerwania ciąży do 12. tygodnia oraz do rzetelnej edukacji seksualnej, jednolite standardy opieki okołoporodowej w Europie, równy dostęp do ginekologa niezależnie od miejsca zamieszkania, jednolitą i równościową politykę urlopów rodzicielskich i prawo do równych zarobków na tym samym stanowisku niezależnie od płci. Jednocześnie Wiosna obiecywała ochronę przed przemocą w rodzinie - szczególnie w zakresie wprowadzenia instrumentów natychmiastowej izolacji sprawcy przemocy. Partia Roberta Biedronia wskazywała także na konieczność wsparcia finansowego z UE na rozwój sieci bezpłatnych żłobków i przedszkoli w Polsce. Ma to, w opinii działaczy tego ugrupowania, pozwolić kobietom na płynny i finansowo opłacalny powrót do pracy.

Ważne miejsce w programie tej partii zajmowała ochrona zdrowia. Wiosna proponowała wprowadzenie jednolitych standardów opieki zdrowotnej w całej Europie oraz kompleksowego systemu dopłat. Jednym z przykładów zgłaszanych propozycji był Europejski Program Walki z Rakiem. W ramach tego projektu zawarto: edukację zdrowotną, ujednolicenie standardów i dostępności badań profilaktycznych, równy dostęp do leków i celowanych terapii, wsparcie finansowe na zakup najnowocześniejszego sprzętu medycznego, koordynację i dofinansowanie badań nad lekami i kuracjami we wszystkich krajach członkowskich oraz nowe standardy rehabilitacji gwarantujące szybki powrót do pełnej sprawności. Proponowano także istotną z polskiej perspektywy zmianę w postaci wprowadzenia europejskiego standardu oczekiwania na lekarza - maksymalnie do 30 dni. Wśród innych propozycji w tym obszarze znalazły się m.in.: stworzenie listy leków kluczowych, które miałyby być dostępne w całej UE' (Wiosna. Europejska ochrona zdrowia, 2019), pełną cyfryzację historii zdrowia pacjenta czy wspieranie działań zmniejszających smog w polskich miastach.

Pośród innych postulatów wyróżniających program Wiosny znalazły się: odpowiednie (bezpieczne i etyczne) zarządzanie danymi i ochrona prywatności, wzmocnienie samorządu terytorialnego ${ }^{2}$ (Wiosna. Środki europejskie dla regio-

${ }^{1}$ „Stworzymy listę leków kluczowych, które muszą być tak samo dostępne we wszystkich państwach członkowskich. Obecnie ceny są negocjowane z firmami farmaceutycznymi przez każde państwo członkowskie oddzielnie. Unia Europejska musi wykorzystać swoją siłę negocjacyjną. Europejska Agencja Leków powinna negocjować ceny dla całej UE" (Wiosna. Europejska ochrona zdrowia, 2019).

2 „Potrzebny jest kolejny etap decentralizacji, likwidacja biurokracji i zmniejszenie kosztów administracyjnych. Dlatego samorządy powinny mieć bezpośredni dostęp do środków europejskich z pominięciem władz centralnych" (Wiosna. Środki europejskie dla regionów, 2019). 
nów, 2019), zmniejszenie obciążeń biurokratycznych poprzez stworzenie Europejskiego Testu Przyjaznego Prawa ${ }^{3}$ (Wiosna. Europa nowej spójności, 2019), wsparcie wolnych mediów, szczególnie na poziomie lokalnym, przez stworzenie Europejskiego Funduszu Wolnych Mediów ${ }^{4}$ (Wiosna. Europa..., 2019) oraz zmiany w polityce wizowej UE ${ }^{5}$ (Wiosna. Europa..., 2019). Proponowano także wprowadzenie Europejskiej Karty Kultury i Sportu umożliwiającą wykorzystanie zawartych tam środków finansowych na wydarzenia sportowe czy kulturalne ${ }^{6}$ (Wiosna. Europejska równość, 2019). Wiosna jako nowe ugrupowanie na polskiej scenie politycznej przedstawiła więc program sytuujący ją na lewo od Koalicji Europejskiej. Dzięki temu partia Biedronia chciała zyskać poparcie osób, które poszukiwały propozycji bardziej wyrazistej niż Koalicja Europejska, szczególnie w kontekście społeczno-kulturowym. W ten sposób chciała przełamać duopol dominujący na polskiej scenie politycznej. Wynik wyborów pokazał jednak, że nie była to próba szczególnie udana, choć zapewniła Wiośnie przekroczenie progu wyborczego.

Przed wyborami do PE w 2019 roku powstała także eurosceptyczna koalicja partii i środowisk prawicowych. Zgłosiła ona komitet wyborczy pod nazwą „Konfederacja Korwin Braun Liroy Narodowcy”. Początkowo przyjęto nawet nazwę „Koalicja Propolska”, co miało wskazywać na przeciwieństwo Koalicji Europejskiej. W skład tego komitetu weszły: KORWiN, Ruch Narodowy, Stowarzyszenie „Skuteczni” (Piotr „Liroy” Marzec), „Pobudka” (Grzegorz Braun), Federacja dla Rzeczypospolitej (Marek Jakubiak) i inne.

Konfederacja przedstawiała program konserwatywno-narodowy i zdecydowanie krytyczny wobec UE. Odwoływała się do wartości narodowych, podkreślała znaczenie tradycji i rodziny w społeczeństwie. Wskazywała na znaczenie religii katolickiej i wartości religijnych w życiu społecznym, podkreślając konieczność prawnej ochrony życia poczętego. Wśród postulatów Konfederacji znalazły się także zdecydowany sprzeciw wobec napływu imigrantów do Europy oraz wobec działań środowisk LGBT. Odrzucano możliwość zawierania małżeństw przez pary homoseksualne i możliwość adopcji przez nie dzieci. Sprzeciwiano się także edukacji seksualnej prowadzonej przez osoby związane ze środowiska-

${ }^{3}$ „Dlatego stworzymy europejski Test Przyjaznego Prawa - system oceny regulacji przed jej wprowadzeniem. Żeby go przejść, regulacje będą musiały być wystarczająco proste, zrozumiałe i łatwe do wdrożenia" (Wiosna. Europa nowej spójności, 2019).

${ }^{4}$, ,...] stworzymy Europejski Fundusz Wolnych Mediów. Ogólnokrajowe i lokalne media, które w swojej działalności promują demokrację i patrzą władzy na ręce, będą mogły liczyć na wsparcie finansowe w postaci grantów" (Wiosna. Europa nowej spójności, 2019).

5 „Unia Europejska powinna stać się jednym obszarem wizowym [...]. Od 2022 roku obowiązywać będzie jednolity paszport europejski zamiast paszportów krajowych". (Wiosna. Europa nowej spójności, 2019).

6 ,„...] wprowadzimy Europejską Kartę Kultury i Sportu. Każdy z nas będzie miał na niej określoną kwotę w miesiącu do wykorzystania na usługi związane ze sportem i kulturą" (Wiosna. Europejska równość, 2019). 
mi organizacji działających na rzecz praw osób nieheteronormatywnych. Jako remedium proponowano Kartę Polskiej Rodziny. „Nie miejmy złudzeń, tęczowi dewianci wyciągają ręce po polskie dzieci. Dokładnie to co dzieje się na zachodzie. Przed czym Polacy uciekają chociażby z Wysp Brytyjskich. [...] Kartą Polskiej Rodziny chcemy zabezpieczyć prawo Polaków, dzieci, młodzieży, do normalnego spokojnego wychowywania przez rodziców i w duchu wartości, które ci rodzice wyznają" (Konfederacja prezentuje Kartę Polskiej Rodziny, 2019) deklarował Robert Winnicki w trakcie przedstawiania tego dokumentu.

Politycy Konfederacji zdecydowanie sprzeciwiali się przyjęciu przez Polskę waluty euro. Jak deklarował Jakubiak: „Złoty polski jest ukonstytuowany w ustawie zasadniczej, jest walutą narodową, jest walutą, która świadczy, że Polska jest wolna i niezależna ekonomicznie" (Nie dla euro w Polsce, tak dla polskiej złotówki, 2019). W ich opinii polska polityka musi być niezależna od obcych rządów (Brukseli, Waszyngtonu, Berlina czy Jerozolimy), a własna waluta jest elementem takiej niezależności. W trakcie kampanii wyborczej podnoszono także sprawę sprzeciwu wobec amerykańskiej ustawy 447 (JUST Act) dotyczącej mienia żydowskiego, jakie pozostało po II wojnie światowej na terenie Polski. Dla części polityków Konfederacji, szczególnie związanych z partią KORWiN, ważne były także postulaty wolnościowe i liberalizm gospodarczy.

W kontekście perspektywy europejskiej najciekawszym dokumentem środowisk tworzących Konfederację jest jednak „POLexit bezpieczne wyjście awaryjne" wydany przez Ruch Narodowy 1 maja 2019 roku - w 15. rocznicę przystąpienia Polski do Unii Europejskiej. Autorzy wskazywali w nim na konieczność przygotowania naszego państwa na opuszczenie UE — bez względu na to, czy dojdzie do tego wskutek decyzji polskiej, czy też niezależnie od woli polskiego rządu czy społeczeństwa. W dokumencie zarzuca się UE, że ogranicza rozwój gospodarczy państw tzw. nowej Unii, w tym prowadzi do utrzymania peryferyjnego charakteru polskiej gospodarki. Wskazuje się też, że UE narzuca państwom członkowskim lewicową agendę w obszarze kultury.

Zdaniem działaczy Ruchu Narodowego kryzysy dotykające UE mogą prowadzić do powstania sytuacji, gdy opuszczenie Unii przez Polskę stanie się koniecznością. Wskazują oni trzy takie możliwości: 1) dezintegrację UE, 2) tzw. cichy rozpad Unii, gdy UE będzie funkcjonowała formalnie, ale państwa przestaną realizować zapisy traktatowe, 3) gdy koszty uczestnictwa Polski w UE staną się „nie do przyjęcia” (POLexit bezpieczne wyjście awaryjne, 2019, s. 5). Jednocześnie autorzy deklarują, że uznają polexit za rozwiązanie najlepsze dla Polski. Wskazują, że na coraz ściślejszej integracji Polski ze strukturami europejskimi zależy najbardziej Niemcom i biznesowi innych państw europejskich. Ugrupowane to w kampanii wyborczej postanowiło walczyć o głosy nie tylko przeciwników obecności Polski w UE, ale i tych, którzy — jak pokazują analizowane uprzednio badania - są krytyczni wobec określonych aspektów integracji europejskiej. 
Konfederacja jednocząc różne ugrupowania antyunijne, zbudowała zdecydowanie eurosceptyczną propozycję wyborczą. Uzupełniła polską scenę partyjną, czyniąc ją zbliżoną pod tym względem do aren partyjnych wielu państw Europy Zachodniej, jak np. Niemcy, Francja czy Holandia. Program i propozycje krytyczne wobec integracji europejskiej i uczestnictwa Polski w tym procesie stały się przedmiotem debaty politycznej. Trafiły także (choć w zróżnicowanym zakresie) do mediów mainstreamowych. Wynik wyborczy Konfederacji pokazał jednak, że w Polsce zapotrzebowanie na taką propozycję polityczną było w 2019 roku niewielkie.

\section{Kampania wyborcza do PE w 2019 roku}

Analizując kampanię wyborczą do PE w 2019 roku, Edoardo Novelli i Bengt Johansson (Novelli, Johansson, eds., 2019) zwrócili uwagę na niski stopień jej internacjonalizacji. W trakcie kampanii tożsamość narodowa była ważniejsza niż europejskie powiązania polityczne (np. uczestnictwo w partiach na poziomie europejskim). W kampanii wyborczej uwidoczniła się przewaga tematów krajowych nad europejskimi. Problematyka potencjalnie europejska, jak np. migracja, także została zaprezentowana z punktu widzenia interesów danego państwa (Włochy, Węgry). Podobnie było w przypadku kwestii związanych ze środowiskiem naturalnym. Jak zauważają autorzy omawianego raportu, problematyka migracyjna częściej występowała w Europie Wschodniej, kwestie środowiska zaś (zmiany klimatu, polityka energetyczna, zrównoważony rozwój) — w państwach członkowskich Europy Zachodniej i Północnej. Pomimo wzrostu znaczenia wielu partii eurosceptycznych w państwach członkowskich UE (np. Francja, Włochy, Holandia czy Wielka Brytania), według opracowania Novellego i Johanssona $\mathrm{w}$ trakcie kampanii partie eurosceptyczne nie miały przewagi. Zauważają oni także, że część partii wcześniej sceptycznych wobec UE teraz ograniczyła swój krytycyzm do konkretnych kwestii czy problemów (Novelli, Johansson, eds., 2019, s. 15). W tej kategorii można ujmować krytycyzm wobec określonych rozwiązań i działań Unii ze strony PiS-u.

Analiza materiałów wyborczych ze wszystkich państw członkowskich ukazała, że w Europie Południowej i Wschodniej dominowały kwestie narodowe lub narodowe i europejskie bardziej niż w Europie Zachodniej czy Północnej. Najsilniej na kwestiach europejskich kampanie wyborcze były skoncentrowane w Belgii, Luksemburgu oraz Szwecji. Najrzadziej problematyka europejska występowała w Bułgarii, Rumunii i Irlandii, natomiast stosunkowo rzadko w Polsce, Grecji, Estonii, na Malcie oraz Litwie. W naszym kraju — według badań Novellego i Johanssona - około 80\% komunikatów dotyczyło tematyki 
narodowej czy narodowej/europejskiej. Działania wyborcze sfokusowane najbardziej na problematyce narodowej występowały w Portugalii, Chorwacji, na Malcie, Litwie oraz, co zrozumiałe w sytuacji brexitu, w Wielkiej Brytanii (ponad 50\%) (Novelli, Johansson, eds., 2019, s. 18).

Analiza materiałów wyborczych z 28 państw członkowskich wskazuje, że pomimo zgłaszanych przez wielu komentatorów obaw o dominację treści eurosceptycznych czy nawet antyunijnych taka sytuacja nie miała miejsca. Pozytywne przedstawienie UE zostało odnotowane w $34,2 \%$ przypadków $(8,9 \%$ zdecydowanie pozytywne, $25,3 \%$ pozytywne), negatywne zaś - w $11,4 \%(7,6 \%$ negatywne, 3,8\% — zdecydowanie negatywne). Jednak ocena ta nie była taka sama we wszystkich państwach. Najwięcej ocen zdecydowanie negatywnych odnotowano w Wielkiej Brytanii i Holandii, najmniej ocen negatywnych z kolei na Cyprze, a także w Estonii, Słowenii, Luksemburgu, Rumunii, na Malcie i Litwie. Oceny pozytywne natomiast wystąpiły stosunkowo często w Finlandii, Belgii, Słowenii, Bułgarii, Hiszpanii i na Cyprze.

W polskiej kampanii wyborczej przeważała perspektywa narodowa/europejska $(41,7 \%)$ oraz narodowa $(37,1 \%)$. Stosunkowo mało z analizowanych przez zespół z Uniwersytetu Marii Curie-Skłodowskiej (Ewa Nowak-Teter, Małgorzata Adamik-Szysiak, Justyna Maguś) materiałów wyborczych dotyczyło perspektywy europejskiej $(9,4 \%)$. Problematyka europejska najczęściej znajdowała się w materiałach Koalicji Europejskiej, a szczególnie wchodzącego w jej skład SLD.

Najmniej elementów dotyczących problematyki europejskiej znalazło się z komunikatach politycznych PiS-u. Należy jednak zauważyć, że w analizowanych badaniach nie poddano ocenie materiałów wyborczych skrajnie prawicowej i antyeuropejskiej koalicji Konfederacja Korwin Braun Liroy Narodowcy. Jak ukazano w niniejszym artykule, problematyka europejska w perspektywie krytycznej oraz problematyka narodowa dominowały w przekazie wyborczym tego ugrupowania. W przypadku materiałów wyborczych partii rządzącej dominowała perspektywa narodowa i na drugim miejscu narodowa/europejska. W przypadku Koalicji Europejskiej obie te perspektywy były obecne w podobnym zakresie (dodatkowo perspektywa europejska). W materiałach Wiosny Biedronia mamy natomiast nieco więcej odniesień do kwestii narodowych, a perspektywa narodowa/europejska jest tu na drugim miejscu.

Ponad połowa analizowanych materiałów wyborczych nie zawierała odniesienia pozytywnego lub negatywnego do UE lub było ono neutralne. Wśród pozostałych dominowały oceny pozytywne $37,6 \%$ (11\% — zdecydowanie pozytywne, $26,6 \%$ - raczej pozytywne). Ocen negatywnych było tylko niecałe $5 \%$. Najwięcej ocen pozytywnych znalazło się w materiałach PO-Koalicji Europejskiej. Oceny negatywne natomiast znalazły się tylko w materiałach PiS-u oraz Kukiz'15 (Nowak-Teter, Adamik-Szysiak, Maguś, 2019, s. 200-204). Tu również wydaje się, że w przypadku uwzględnienia materiałów Konfederacji wyniki, szczególnie w zakresie odniesienia negatywnego do UE, byłyby inne. 


\section{Wyniki wyborów w Europie i w Polsce}

Wybory do PE odbyły się w dniach 23-26 maja 2019 roku. Należy podkreślić, że cieszyły się one wyższym niż w poprzednich latach uczestnictwem wyborców. Frekwencja w całej UE wyniosła 50,66\% i była prawie o $8 \%$ wyższa niż w 2014 roku. Pomimo wyrażanych wcześniej obaw dotyczących znaczącego wzrostu poparcia dla partii eurosceptycznych większość głosów otrzymały partie mające dotychczas największe frakcje w PE. Najwięcej mandatów uzyskała Europejska Partia Ludowa (182 mandaty — 24,23\%). Z kolei na drugim miejscu znalazł się Postępowy Sojusz Socjalistów i Demokratów (154 mandaty - 20,51\%). Trzecie miejsce zajęli liberałowie, tworzący frakcję pod zmienioną nazwą Renew Europe - Odnowić Europę (108 mandatów - 14,38\%). Pozostałe frakcje wprowadziły do parlamentu poniżej 100 posłów. Na następnych miejscach znaleźli się zatem Zieloni/Wolne Przymierze Europejskie (74 mandaty - 9,85\%), eurosceptyczna Tożsamość i Demokracja (73 mandaty-72\%), Europejscy Konserwatyści i Reformatorzy (62 mandaty - 8,26\%) oraz Konfederacyjna Grupa Zjednoczonej Lewicy Europejskiej/Nordycka Zielona Lewica (41 mandatów - 5,46\%). Całości dopełniało 57 posłów niezrzeszonych.

Na uwagę zasługuje nie tylko wyższa frekwencja, ale także większa niż dotychczas liczba kobiet wybranych do PE. W 2019 roku stanowiły one 41\% eurodeputowanych. Jest to najwyższy wynik w historii wyborów europejskich. Wzrost liczby kobiet w PE wyniósł od 16\% w 1979 roku do $41 \%$ w ostatnich wyborach. Taki wzrost dotyczy także liczby polskich posłanek do PE. W pierwszych wyborach w 2004 roku było to $15 \%$, z kolei w roku 2019 - już $35 \%$.

W Polsce kampania wyborcza do PE była bardzo silnie uwarunkowana wewnętrznym procesem (konfliktem) politycznym. To uwarunkowania wewnętrzne i pragmatyka polityczna związana $\mathrm{z}$ ordynacją wyborczą były powodem działań integracyjnych po stronie opozycyjnej. Doprowadziło to do zgłoszenia przez większość stronnictw opozycyjnych jednej koalicyjnej listy kandydatów pod nazwą Koalicji Europejskiej. Interpretacja tej nazwy miała stać się siłą napędową kampanii wyborczej, budującą komunikat oparty na przeciwstawieniu stronnictw europejskich (czy też proeuropejskich, prounijnych) rządzącej partii. W skład tej koalicji wyborczej wchodziły: PO, Polskie Stronnictwo Ludowe, SLD, Nowoczesna, Partia Zieloni, Inicjatywa Polska. Utworzona koalicja wyborcza mieściła się w logice krajowego sporu politycznego. Jednak z punktu widzenia potencjalnych miejsc $\mathrm{w}$ PE znaleźli się w niej kandydaci zarówno Europejskiej Partii Ludowej, jak i Postępowego Sojuszu Socjalistów i Demokratów. Nie była to więc sytuacja klarowna z perspektywy europejskich partii politycznych.

W wyborach do PE 2019 roku na polskiej scenie politycznej pojawiła się także nowa partia o orientacji lewicowo-liberalnej — Wiosna. W sytuacji przy- 
łączenia dwóch innych ugrupowań lewicowych (SLD i Inicjatywa Polska) do Koalicji Obywatelskiej stała się ona ważnym punktem odniesienia dla bardziej progresywnych grup wyborców, szczególnie z dużych miast. Jej atutem w trakcie kampanii wyborczej był stosunkowo dobrze rozpoznawany lider — Robert Biedroń. Samodzielny start tego ugrupowania stał się jednak przedmiotem krytyki nie tylko ze strony PiS-u i związanych z tą partią mediów, ale także ze strony części mainstreamowych mediów liberalnych. Wywierały one presję na zjednoczenie maksymalnie wielu ugrupowań opozycyjnych wobec rządu wokół projektu Koalicji Europejskiej.

Najpoważniejszym kandydatem do zwycięstwa w wyborach była partia sprawująca władzę - PiS wraz ze stronnictwami sojuszniczymi: Sprawiedliwa Polska i Porozumienie. Koalicja Zjednoczonej Prawicy prezentowała się jako ugrupowanie walczące o polskie interesy i krytyczne wobec wielu aspektów funkcjonowania Unii, ale nie przeciwne udziałowi Polski w UE. Poza Zjednoczoną Prawicą, Koalicją Europejską i Wiosną listy kandydatów zgłosiły także: Konfederacja KORWiN Braun Liroy Narodowcy, ugrupowanie Kukiz'15, koalicja Lewica Razem, w której skład wchodziły: Partia Razem, Unia Pracy i Ruch Sprawiedliwości Społecznej oraz Polska Fair Play Bezpartyjni Gwiazdowski i inne mniejsze ugrupowania.

W wyborach europejskich w Polsce zwyciężył PiS, uzyskując 45,38\% głosów. Dało to 26 mandatów posłom do Parlamentu Europejskiego, którzy znaleźli się w Grupie Europejskich Konserwatystów i Reformatorów. Drugie miejsce zajęła Koalicja Europejska. Uzyskała ona 38,47\% głosów, co dało 22 mandaty. Wybrani z tej listy koalicyjnej eurodeputowani zasilili w większości Grupę Europejskiej Partii Ludowej - 17 mandatów. Pozostałych 5 wybranych posłów znalazło się w Grupie Postępowego Sojuszu Socjalistów i Demokratów. Trzecie miejsce zajęła debiutująca Wiosna, uzyskując 6,06\% głosów. Wybranych 3 eurodeputowanych tego ugrupowania także zasiliło Grupę Postępowego Sojuszu Socjalistów i Demokratów. Pozostałe partie i koalicje wyborcze nie uzyskały żadnego mandatu w Parlamencie Europejskim. Czwarte miejsce zajęła eurosceptyczna Konfederacja KORWiN Braun Liroy Narodowcy (4,55\%), następnie ugrupowanie Kukiz'15 (3,69\%) oraz koalicja Lewica Razem (1,24\%).

\section{Podsumowanie}

Wybory do PE w 2019 roku w Polsce zaskoczyły wysoką frekwencją wyborczą. Jednak już ich wynik w wysokim stopniu stanowił odzwierciedlenie sytuacji na krajowej scenie politycznej. Kampania wyborcza w dużej mierze była także podporządkowana krajowej logice wyborczej. Wiązało się to z kalen- 
darzem wyborczym w 2019 roku. Silna polaryzacja sceny politycznej znacząco utrudniała zaistnienie innym podmiotom politycznym (Wiosna, Konfederacja, Lewica Razem). Większość ugrupowań biorących udział w wyborach prezentowała dominujące w społeczeństwie przekonanie o potrzebie utrzymania członkostwa Polski w UE. Analiza materiałów wyborczych pozwala na potwierdzenie postawionej pierwszej hipotezy badawczej.

Przeprowadzone analizy pozwoliły na weryfikację także drugiej hipotezy. Partie sceptyczne wobec UE, jak np. PiS czy Konfederacja, odnosiły się krytycznie do tych obszarów integracji europejskiej, które są przez część badanych oceniane negatywnie. Krytycyzm dotyczył m.in. wpływu uczestnictwa w Unii na polską tradycję, rodzinę czy religijność. Podkreślano także obronę polskiej suwerenności. Należy też zauważyć, że w tej kampanii wyborczej pojawiły się propozycje zdecydowanie antyunijne. Przedstawiciele Konfederacji opowiadali się za opuszczeniem przez Polskę UE, czego przykładem jest omawiany w tym opracowaniu dokument Ruchu Narodowego.

Jak wynika $\mathrm{z}$ analizowanych badań socjologicznych, pomimo utrzymującego się bardzo wysokiego poparcia dla uczestnictwa Polski w UE obserwujemy w ostatnich latach przyrost ocen krytycznych wobec niektórych konsekwencji uczestnictwa Polski w Unii w odniesieniu do szczegółowych obszarów życia, jak rodzina, religia czy odczucie utraty kontroli nad rzeczywistością polityczną. Należy zwrócić szczególną uwagę na ten proces, gdyż w sytuacji kryzysowej może on ulec nasileniu. Może też oddziaływać na partie polityczne, zwiększając ich możliwości uzyskiwania poparcia wyborczego (Konfederacja) lub modyfikując agendę polityczną, by stała się bardziej krytyczna wobec UE (PiS). W efekcie w kontekście kryzysowym może to stworzyć płaszczyznę do działań na rzecz wyprowadzenia w najbliższej przyszłości Polskie z UE.

\section{Bibliografia}

15 lat członkostwa Polski w Unii Europejskiej (2019). Komunikat z badań CBOS nr 59. Warszawa, kwiecień 2019.

Cooper, L., Dunin-Wąsowicz, R., Milanese, N. (2019). The Dawn of a Europe of Many Visions. London: LSE Conflict and Civil Society Research Unit.

Dahl, R.A., Stinebrickner, B. (2007). Współczesna analiza polityczna. Przeł. P.M. Kazimierczak. Warszawa: Wydawnictwo Naukowe Scholar.

Devine, F. (2006). Metody jakościowe. W: D. Marsh, G. Stoker (red.), Teorie i metody w naukach politycznych. Przeł. J. Tegnerowicz. Kraków: Wydawnictwo Uniwersytetu Jagiellońskiego.

Dyduch, J. (2019). Polsko-niemieckie stosunki bilateralne z uwzględnieniem perspektywy multilateralnej. W: Z. Czachór, T. Marcinkowski (red.), Polska - 
Niemcy - Unia Europejska w procesie zmian. Gorzów Wielkopolski: Wydawnictwo Naukowe Akademii im. Jakuba z Paradyża.

Garlicki, J. (2010). Socjologiczny wymiar studiów europejskich. W: K.A. Wojtaszczyk, W. Jakubowski (red.), Studia europejskie. Zagadnienia metodologiczne. Warszawa: Wydawnictwo Akademickie i Profesjonalne.

Guz-Vetter, M. (2019). Stosunki polsko-niemieckie w kontekście procedury kontroli praworządności Komisji Europejskiej wobec Polski. W: Z. Czachór, T. Marcinkowski (red.), Polska - Niemcy - Unia Europejska w procesie zmian. Gorzów Wielkopolski: Wydawnictwo Naukowe Akademii im. Jakuba z Paradyża.

Hix, S. (2010). System polityczny Unii Europejskiej. Przeł. A. Komasa. Warszawa: Wydawnictwo Naukowe PWN.

Jackiewicz, A., (2014). Wybory do Parlamentu Europejskiego jako wybory drugiej kategorii (second-order elections). Uwagi na temat przyczyn, konsekwencji oraz prób przeciwdziałania niskiej frekwencji wyborczej. Przeglą Sejmowy, 2(121), $9-21$.

Jakubowski, P. (2016). Kampania wyborcza do Parlamentu Europejskiego w 2014 roku w Polsce — analiza strategii i taktyk wyborczych. Prawo i Polityka, 7, $7-29$.

Jaskulski, A. (2019). Konteksty i uwarunkowania polskiej polityki europejskiej w latach 2004-2014. Poznań: Wydawnictwo Naukowe Wydziału Nauk Politycznych UAM

Jestem realistka - chce więcej Europy (2019). Z Danutą Hubner rozmawia Jakub Bodziony. Pobrano z: https://kulturaliberalna.pl/2019/04/30/hubner-kampaniawybory-europejskie-wywiad/ (data dostępu: 13.09.2019).

John, P. (2006). Metody ilościowe. W: D. Marsh, G. Stoker (red.), Teorie i metody w naukach politycznych. Przeł. J. Tegnerowicz. Kraków: Wydawnictwo Uniwersytetu Jagiellońskiego.

Konfederacja prezentuje Kartę Polskiej Rodziny (2019). Pobrano z: https://wolnosc. pl/konfederacja-prezentuje-karte-polskiej-rodziny/ (data dostępu: 10.01.2020).

Kownacki, T. (2005). Parlament Europejski. W: K.A. Wojtaszczyk (red.), System instytucjonalny Unii Europejskiej. Warszawa: Oficyna Wydawnicza Aspra-JR.

Krastev, I. (2018). Co po Europie? Przeł. A. Gustowski. Warszawa: Wydawnictwo Krytyki Politycznej.

Leach, R. (2004). Europe. A Concise Encyclopedia of the European Union. London: Profile Books.

Łatwo możemy stracić dorobek wielu pokoleń (2019). Z Jadwigą Emilewicz rozmawiają Łukasz Pawłowski i Jakub Bodziony. Pobrano z: https://kulturali beralna.pl/2019/05/14/emilewicz-wybory-europejskie-wywiad/ (data dostępu: 11.09.2019).

Marcinkowski, T. (2014). Polskie partie polityczne wobec procesu integracji europejskiej 1989-2005. Gorzów Wielkopolski: Wydawnictwo Naukowe PWSZ im. Jakuba z Paradyża.

Marcinkowski, T. (2017). Kryzys migracyjny a poczucie bezpieczeństwa. Polska, Niemcy, pogranicze polsko-niemieckie. W: Z. Czachór, T. Marcinkowski (red.), Polska - Niemcy - Unia Europejska. Razem czy osobno? Warszawa: Dom Wydawniczy Elipsa. 
Marcinkowski, T. (2019a). Europa, bezpieczeństwo i suwerenność w polityce zagranicznej Zjednoczonej Prawicy. W: Z. Czachór, A. Jaskulski (red.), Polska polityka europejska. Wyzwania krajowe i międzynarodowe. Poznań: Wydawnictwo Naukowe Wydziału Nauk Politycznych i Dziennikarstwa UAM.

Marcinkowski, T. (2019a). Migration Crisis versus the Control of the Borderlines within the European Union. Rocznik Integracji Europejskiej, 13, s. 159-174.

Materiat KWW Koalicja Europejska PO PSL SLD .N Zieloni (2019). Pobrano z: https://platforma.org/aktualnosci/przyszlosc-polski-wielki-wybor (data dostępu: 15.04.2019).

Nie dla euro w Polsce, tak dla polskiej złotówki (2019). Pobrano z: https://wolnosc. $\mathrm{pl} /$ nie-dla-euro-w-polsce-tak-dla-polskiej-zlotowki/ (data dostępu: 27.01.2020).

Nie zgadzamy się na podwójne standardy w UE (2019). Pobrano z: http://pis.org. $\mathrm{pl} /$ aktualnosci/nie-zgadzamy-sie-na-podwojne-standardy-w-ue (data dostępu: 2.09.2019).

Novelli, E., Johansson, B. (eds.) (2019). 2019 European Elections Campaign. Images, Topics, Media in the 28 Member States. Brussels: Public Opinion Monitoring Unit.

Nowak-Teter, E., Adamik-Szysiak, M., Maguś, J. (2019). Poland. In: E. Novelli, B. Johansson (eds.), 2019 European Elections Campaign. Images, Topics, Media in the 28 Member States. Brussels: Public Opinion Monitoring Unit.

Obrona polskich interesów to misja polskiej delegacji (2019). Pobrano z: http:// pis.org.pl/aktualnosci/obrona-polskich-interesow-to-misja-naszej-delegacji-dope4.2019 (data dostępu: 12.07.2019).

Orłowska, M. (2014). Neorealistyczne interpretacje procesu integracji europejskiej. Historia i Polityka, 11(18), 47-54.

POLexit bezpieczne wyjście awaryjne. Ruch Narodowy, 1 maja 2019 (2019). Pobrano z: https://ruchnarodowy.net/wp-content/uploads/PolExit-Bezpieczne-wyj\%C5\% 9Bcie-awaryjne-ver1_2.pdf (data dostępu: 27.01.2020).

Rewizorski, M., Przybylska-Maszner, B. (2012). System instytucjonalny Unii Europejskiej po traktacie z Lizbony. Aspekty polityczne i prawne. Warszawa: Wydawnictwo Difin.

Ruszkowski, J. (2007). Wstęp do studiów europejskich. Warszawa: Wydawnictwo Naukowe PWN.

Silverman, D. (2008). Prowadzenie badań systemowych. Przeł. J. Ostrowska. Warszawa: Wydawnictwo Naukowe PWN.

Stępińska, A., Wrześniewska-Pietrzak, M. (2006). Jedność w różnorodności komunikacja przez pryzmat wartości w kampanii do Parlamentu Europejskiego (2004). W: I. Kamińska-Szmaj, T. Piekota, M. Zaśko-Zielińska (red.), Oblicza komunikacji 1. T. 1: Perspektywy badań nad tekstem, dyskursem i komunikacją. Kraków: Krakowskie Towarzystwo Popularyzowania Wiedzy o Komunikacji Językowej Tertium.

Unia się kurczy (2019). Z Witoldem Waszczykowskim rozmawia Łukasz Pawłowski. Pobrano z: https://kulturaliberalna.pl/2019/04/30/witold-waszczykowskiwywiad-wybory-unia-europejska/ (data dostępu: 2.09.2019). 
Wierzchowska, A. (2010). Studia europejskie z perspektywy nauk politycznych. W: K.A. Wojtaszczyk, W. Jakubowski (red.), Studia europejskie. Zagadnienia metodologiczne. Warszawa: Wydawnictwo Akademickie i Profesjonalne.

Wiosna. Europa nowej spójności (2019). Pobrano z: https://wiosnabiedronia.pl/pro gram/europa-nowej-spojnosci (data dostępu: 14.11.2019).

Wiosna. Europejska ochrona zdrowia (2019). Pobrano z: https://wiosnabiedronia.pl/ program/europejska-ochrona-zdrowia (data dostępu: 14.11.2019).

Wiosna. Europejska równość (2019). Pobrano z: https://wiosnabiedronia.pl/program/ europejska-rownosc (data dostępu: 14.11.2019).

Wiosna. Środki europejskie dla regionów (2019). Pobrano z: https://wiosnabiedronia. $\mathrm{pl} /$ program/srodki-europejskie-dla-regionow (data dostępu: 14.11.2019).

Zielonka, J. (2014). Koniec Unii Europejskiej? Warszawa: Polski Instytut Spraw Międzynarodowych. 